will welcome a more important agency. This is not merely Dr DuBridge's own inclination but the way the wind is blowing.

The retiring Science Adviser, Mr Donald Hornig, does, however, emphasize that the office is such that nobody can predict in advance just how his preconceived notions will work out in practice. To this extent it is like the presidency itself. He said today that it would have been impossible to predict the events of the five years during which he has been a member of the White House staff from his public statements before taking the job.

Looking back over this period, Dr Hornig said that one of the most striking developments had been the way in which "science has become a part of everything". In other words, he said, people and reientists had become more aware of the problems occasioned by scientific and technological developments-pollution and other environmental problems, for example. The result was "a new interaction between the scientists and social scientists" which does not, in his view, necessarily mean that "the physical scientists have to give way to the social scientists" but merely that they have to be prepared to conduct a continuing dialogue-the fasionable word-with them.

Dr Hornig also drew attention to the way in which the Office of Science and Technology "has gelled as part of the government structure". For one thing, this means that the office is now acknowledged to be a necessary partner in making decisions on all kinds of matters from defence to the distribution of funds for scientific research at the universities. Dr Hornig said today that the office could do a valuable and creative job by bringing together officials in different agencies concerned with different aspects of the same essentially scientific problems. At the same time, its role as the routine examiner of the scientific components in the Federal budget has been established and accepted. In pace with the growth of its responsibilities the size of the office staff has increased from half a dozen in the mid-fifties to ten under Dr Wiesncr, to 25 at present. Dr Hornig said today that he considered the essential part of the job was that of providing a nimble staff of scientists who eould act on behalf of the President in all kinds of interdepartmental problems, which had led him to "get out of this office" any responsibilities which could be dealt with clsewhere. But, Dr Hornig said, there was pressure-particularly from Congress--to see that some arm of the Federal Government took a more deliberate and analytical view of the management of science within and outside the Federal Government, which in turn created "an incipient bureaucracy".

Dr Hornig, who will become an executive of the Fastman Kodak Company and a professor at the University of Rochester when he leaves Washington, says that at present he has only the vaguest plans for how he will carry out these two assignments. Like many other officials leaving before the new Administration comes in, he says that "it's going to be a terrible wrench" to leave the White House and that his job "has been one of the most stimulating things T have ever done".

\title{
Intellectuals of the World at Odds
}

\section{from our Special Correspondent, Princeton, December}

A Remarkable symposium held here from December 1-3 has left the eighty or so participants, and the somewhat larger number of journalists who hung fitfully on their words, with a sense of impending crisis but with no clear view of what kinds of solutions may be possible. The symposium was organized by the Association for Cultural Freedom, the organization which has evolved from that which publishes Encounter, Minerva and several others, and which ran into trouble a year ago when it turned out to be the recipient of money from the Central Intelligence Agency of the United States. Even the association's enemies agree that the CIA could hardly have spent its money in a more enlightened way.) The main business of the symposium was the condition of the United States, internally and externally, and the likely course of events in the next few years. The participants included ex-ambassadors such as Professor John K. Galbraith, Mr George Ball and $\mathrm{Mr}$ (now Professor) George Kennan, as well as Mr Henry Kissinger, the newly appointed special assistant to the President-elect. The United States contingent also included several university professors, editors of journals, student leaders (some now graduated to the faculties of their universities) and the advocates of black power in various forms.

The confusion created by the discussion between this group and the visitors from abroad is well illustrated by the discussion on the racial problem in the United States. Will there really be a period of scparate development for the black and white communities in the United States? Outsiders were surprised to find that this seems now to be the goal not merely of the Black Power people but-reluctantly perhaps-of some white liberals as well. But in any case, is such a course practical, let alone safe? Nobody seems to know for sure. But there was similar doubt about the way in which the universities are developing in the United States and Europe. At the end of the symposium, there was an unresolved conflict between those who consider there has been a dangerous erosion of authority within the universities, coupled perhaps with an unwillingness to yield to reasonable demands by the students, and those who looked for a much more radical change than there has been so far between the faculties and the students. On external policy, for the United States, it is perhaps remarkable that the symposium paid comparatively less attention to problems such as aid to developing countries than to the military problems of western and central Europe. In general, the symposium seems to have been a vivid demonstration that abstract discussions among bright people are more effective as a means of identifying problems than of solving them. 